\title{
ANALISIS SOSIOLOGI EKONOMI PADA TAMBANG RAKYAT \\ (Kajian Terhadap Kegiatan Ekonomi Dalam Tambang Rakyat Intan di Cempaka, Banjarbaru, Kalimantan Selatan)
}

\author{
Laila Azkia \\ Program Studi Pendidikan Sosiologi, Fakultas Keguruan dan Ilmu Pendidikan, \\ Universitas Lambung Mangkurat \\ laila_azkia@yahoo.com
}

\begin{abstract}
ABSTRAK
Tambang rakyat merupakan tambang yang menarik untuk diteliti. Ada berbagai kegiatan ekonomi di tambang rakyat. Tulisan ini mecoba menganalisis kegiatan ekonomi tersebut dengan konsep-konsep yang ada dalam sosiologi ekonomi. Konsep yang penulis gunakan adalah sektor informal dan free rider. Tambang rakyat yang penulis amati adalah tambang rakyat intan di Cempaka, Kota Banjarbaru, Kalimantan Selatan. Terdapat banyak aktor yang ikut ambil bagian dalam kegiatan ekonomi di tambang rakyat tersebut. Transaksi yang menguntungkan adalah daya tarik tersendiri dari kegiatan ekonomi di sana. Tujuan dari tulisan ini adalah pertama penulis menyoroti peran-peran yang sedang dimainkan oleh aktor-aktor dalam tambang rakyat tersebut, baik itu pendulang, pengusaha atau pedangan, dan pemerintah kota. Kedua penulis memfokuskan pada analisis terhadap kegiatan ekonomi yang berlangsung di tambang rakyat tersebut. Penulis menggunakan metode kualitatif, dengan data-data sekunder baik dari Pemeritah Daerah maupun hasil riset sebelumnya. Sumber dari data sekunder tersebut penulis sertakan di daftar pustaka. Hasil dari analisis ini dapat disimpulkan bahwa tambang rakyat sebagai sebuah sektor informal selama ini aktifitas di dalamnya tidak mendapat ijin, tetapi aktifitas di dalamnya dibiarkan begitu saja oleh pemerintah. Banyak free rider atau pembonceng gratis dalam aktifitas ekonomi di tambang. Free Rider adalah mereka yang tidak punya modal dalam usaha tambang tetapi mengambil keuntungan dari tambang.
\end{abstract}

Kata kunci : tambang rakyat, kegiatan ekonomi, sosiologi ekonomi, free rider dan sektor informal

\begin{abstract}
The artisanal mining is an interesting mine for research. There are many different economic activities in artisanal mining. This paper tries to analyze the economic activities with the concepts that exist in economic sociology. The concepts that authors use is the informal sector and free rider. The Artisanal mining that author observed is Diamond Artisanal Mining in Cempaka, Banjarbaru, South Kalimantan. There are many actors who took part in the economic activities in mine people. The transaction was a profitable attraction of economic activity there. The purpose of this paper is the first the author highlights the roles being played by actors in the artisanal mining, there are pendulang, entrepreneurs or trader and the Government. The second, author focus on the analysis of the economic activities that take place in artisanal mining. The author uses a qualitative method, with secondary data either from the government and the results of previous research. A secondary data source from the author include in the bibliography. The results from this analysis it can be concluded that artisanal mining as an informal sector during these activities there in did not get a permit, but activities therein are left well enough alone by the Government. Many free rider or free ridership in economy activities in artisanal mining. Free Riders are those who don't have the capital in an effort to mine but take more advantage of artisanal mining.
\end{abstract}

Keywords: people's mine, economic activities, economic sociology, free rider and the informal sector 


\section{PENDAHULUAN}

Sumber daya alam yang ada di teritorial Indonesia sudah ada dan diketahui sejak jaman dulu. Sumber daya alam jugalah yang membuat penjajah datang dan menjajah teritorial Indonesia. Penjajah datang dengan tujuan utama yaitu menguasai sumber daya alam dalam hal ini yang mereka tau pertama adalah dalam bentuk hasil pertanian berupa rempah-rempah. Seiring dengan berjalannya waktu penjajah menyadari bahwa harta yang ada di teritorial Indonesia bukan hanya hasil pertanian melainkan juga tambang. Sebelum kedatangan penjajah, masyarakat Indonesia bisa dengan mudah memanfaatkan hasil Sumber Daya Alam yang ada. Namun penjajah datang membawa berbagai peraturan yang membatasi rakyat menggunakan sumber daya alam. Sumber daya hasil hutan maupun hasil tambang yang diketahui belakangan dibatasi penjajah lewat peraturan. Sedikit demi sedikit intervensi penguasa masuk dalam ranah pemanfaatan sumber daya alam yang selama ini kedaulatannya dimiliki oleh rakyat secara umum.

Indonesia memiliki dua jenis tambang yaitu tambang skala besar dan tambang skala kecil. Fokus tulisan ini adalah pada tambang skala kecil yaitu tambang rakyat. Tambang rakyat adalah tambang yang secara turun temurun dikerjakan oleh masyarakat atau penduduk setempat baik secara perorangan maupun kelompok dengan manajemen secara tradisional (As'ad 2005:2). Selama ini telah banyak dilakukan penelitian yang berkenaan dengan tambang besar atau dalam hal ini perusahaan tambang. Penelitian tersebut dilakukan dengan menggali beberapa aspek terkait seperti relasi yang terjalin antara negara (state), perusahaan (corporation) dan masyarakat (community). Beberapa penelitian menunjukkan relasi yang tidak seimbang yaitu terjadinya konflik kepentingan di dalamnya, di mana corporate memiliki kuasa yang lebih. Menurut penulis sangat sedikit penelitian yang mencoba mengangkat persoalan pada tambang-tambang kecil terutama dalam hal ini tambang rakyat (artisanal mining). Padahal persoalan tambang rakyat adalah persoalan hidup rakyat kecil yang menggantungkan hidup.

Istilah tambang rakyat didefinisikan dalam UU No. 11 tahun 1967 sebagai Pertambangan Rakyat; yaitu satu usaha pertambangan bahan-bahan galian dari semua golongan a, b dan c seperti yang dilakukan oleh rakyat setempat secara kecil-kecilan atau secara gotong-royong dengan alat-alat sederhana untuk pencaharian sendiri. Pertambangan Rakyat bertujuan memberikan kesempatan kepada rakyat setempat dalam mengusahakan bahan galian untuk turut serta membangun Negara di bidang pertambangan dengan bimbingan Pemerintah. Pertambangan Rakyat hanya dilakukan oleh Rakyat setempat yang memegang Kuasa Pertambangan (izin) Pertambangan Rakyat. UU No. 11 Tahun 1967 dilaksanakan melalui PP 
No. 32 Tahun 1969. Dalam ketentuan ini ditentukan bahwa pertambangan rakyat dapat dilakukan setelah mendapat Surat Keputusan Izin Pertambangan Rakyat yang dikeluarkan oleh menteri. Di mana Surat Keputusan Izin Pertambangan Rakyat adalah Kuasa Pertambangan yang diberikan oleh Menteri kepada Rakyat setempat untuk melaksanakan usaha pertambangan secara kecil-kecilan dan dengan luas wilayah yang sangat terbatas.

Pada tulisan ini penulis akan memfokuskan pada tambang rakyat intan yang ada di Cempaka, Kota Banjarbaru, Kalimantan Selatan. Tambang rakyat tersebut telah ada sejak puluhan tahun yang lalu. Mendulang adalah istilah yang dikenal masyarakat Banjar dan menjadi pekerjaan sebagian dari masyarakat di sana. Media Indonesia menyebutkan bahwa tahun 2011 masih ada 200 kelompok pendulang yang beroperasi di empat wilayah, yaitu Kelurahan Cempaka, Sungai Tiung, Bangkal dan Palam. Jumlah pendulang masih sekitar 1.000 orang. Sedangkan jumlah warga yang menggatungkan hidup dari kegiatan itu diperkirakan lebih dari 7.000 jiwa.

Proses pendulangan dilakukan dengan cara tradisional serta dengan mesin pompa. Proses tersebut dimulai dengan menembak lubang galian dengan menyemprotkan air lewat pipa. Tanah serta pasir yang bercampur bebatuan yang terkikis di dasar lubang kemudian disedot menggunakan mesin pengisap. Setelah itu pendulang melakukan proses penyaringan dengan bantuan sebuah anjungan berbentuk menara yang diletakkan di bibir lubang galian. Meterial hasil saringan inilah yang dikumpulkan dalam sebuah kolam dan kemudian mulai dipilih atau didulang. Daerah pendulangan itu bukan daerah yang sempit, luasnya sekitar 2.000 hektar. Sedangkan lubang yang dibuat rata-rata sedalam 20 meter. Lubang-lubang yang digali itulah yang sangat membahayakan. Pendulangan rakyat di Cempaka tersebut adalah menggunakan sistem "dumping", yaitu suatu cara penambangan dengan mengupas tanah permukaan yang kemudian dilanjutkan dengan penggalian, namun seletah selesai penambangan, lapisan tanah atas (top soil) tidak dikembalikan ke tempat asalnya (As'ad 2005:30). Tahun 2010, tercatat telah terjadi delapan kali tanah longsor yang menewaskan 14 orang yang tertimbun di lubang galian tersebut.

Proses mencari dan menemukan intan bukanlah perkara mudah, para pendulang harus melawan berbagai rintangan. Rintangan alam yang mereka lawan tanpa pengaman yang ketat membuat aktivitas penuh bahaya itu setiap saat bisa merenggut nyawa, seperti yang dialami oleh rekan pendulang lain. Intan yang dicari pun terkadang ditemukan namun lebih sering tidak ditemukan. Hasil penjualan intan yang mereka temukan harus dibagi dengan pemilik modal yaitu mereka yang menyediakan mesin, bahan bakar dan peralatan penggalian untuk mengeruk tanah. Kebanyakan dari mereka bekerja dengan terikat pada pemilik modal, 
sehingga intan yang mereka temukan harus dijual kepada pemilik modal. Penjualan tersebut tentunya dengan harga yang sangat minim. Keharusan menjual intan dengan pemilik modal membuat harga intan tersebut dibeli dengan harga rendah, oleh karena itu imbalan dari proses panjang yang dilakukan pendulang tidak sepadan.

Mendulang intan adalah profesi yang sangat sulit untuk mencapai mobilitas sosial naik. umumnya pendulang hanya berkutat pada ritme kehidupan yang sama. Intan yang didapat, kemudian dijual dengan harga minim, uang hasil penjualan dipakai untuk kebutuhan pokok sehari-hari. Sehingga kemiskinan terus menjadi lingkaran setan yang dialami oleh pendulang intan di Banjarbaru tersebut. Mengingat intan yang dijual di lokasi tergolong murah, hal ini dikarenakan kebanyakan pendulang maupun pembeli awal menjual intan mereka dalam bentuk belum dipotong. Selain masalah sosial yaitu kemiskinan yang diperoleh dari proses pendulangan tersebut, masalah lingkungan juga tidak kalah mengkhawatirkan. Seperti kebanyakan permasalahan pertambangan di Indonesia, pertambangan intan di Kalimantan Selatan ini juga menimbulkan dampak kerusakan lingkungan. Proses mencari intan dengan membuka lubang-lubang besar yang tidak ditutup lagi telah mengakibatkan terjadinya kubangan air dengan kandungan asam yang sangat tinggi (karena bawah tanah). Proses pencucian atau pelenggangan telah mencemari tanah, sehingga mematikan berbagai jenis tumbuhan yang hidup di atasnya. Limbah yang dihasilkan oleh tambang ini juga mencemari sungai yang airnya dimanfaatkan warga sekitar untuk keperluan sehari-hari mereka.

Intan yang dihasilkan oleh tambang rakyat di Cempaka, Kalimantan Selatan, sebenarnya merupakan intan dengan kualitas terbaik, ini menurut ahli batu mulia. Kualitas terbaik yang dimiliki intan tersebut dikarenakan intan tersebut berjenis sekunder. Artinya intan tersebut telah larut terbawa arus sungai dari tempat pertama intan itu terbentuk. Ini menyebabkan intan Cempaka mengalami seleksi dari alam sehingga intan tersebut lebih keras dan padat. Sedangkan intan yang dihasilkan di Afrika umumnya adalah intan jenis primer, sehingga lebih lunak dan mudah pecah.

Menilik ke sebuah pertokoan permata yang terkenal di Martapura, di mana ada banyak tokotoko permata yang berjejeran di sana menjual perhiasan batu mulia terutama intan. Dari sini kita dapat melihat bahwa ada peredaran Intan yang besar di daerah tersebut. Banyak pedagang dari berbagai daerah bahkan luar pulau yang ramai memberli intan di sana. Bahkan ekspor ke luar negeri juga telah banyak dilakukan oleh pedagang intan yang besar. Martapura memang terkenal sebagai daerah penghasil intan, dan jika ingin membeli intan dengan kualitas yang bagus serta dengan berbagai macam pilihan, maka Pusat Pertokoaan Perhiasan Cahaya Bumi 
Selamat-lah yang menjadi jawaban. Transaksi intan dan permata lain cukup besar terjadi di pertokoan tersebut. Perdagangan intan tersebut tentunya memberikan keuntungan yang tidak sedikit bagi banyak pihak di sana.

Namun sayangnya keuntungan ini tidak dibarengi dengan kesejahteraan para pendulang maupun warga masyarakat sekitar pendulangan yang terkena imbas negatif dari pendulangan tersebut. Lahan dieksploitasi dengan begitu gencarnya, begitu banyak lubang digali, begitu banyak limbah mengalir ke sungai dan betapa sering banjir melanda adalah tanda mata yang diberikan pemerintah dan pengusaha besar di daerah pendulangan ini.

Dulu berdiri sebuah perusahaan di tambang rakyat intan tersebut, yaitu PT Galuh Cempaka. Tahun 2007 perusahaan tersebut memberikan royalti dari penjualan intan sebesar Rp.1,5 milyar kepada Pemerintah Kota Banjarbaru. Media Indonesia menyebutkan bahwa diperkirakan hasil yang diperoleh dari pertambangan rakyat di Cempaka bisa lebih besar lagi. Sehingga di media yang sama dikatakan bahwa "Pendapatan Asli Daerah (PAD) Kota Banjarbaru hingga tahun 2007 lalu telah mencapai Rp.19,5 miliar. Namun hingga kini kontribusi dari transaksi intan yang berasal dari pertambangan rakyat di Kecamatan Cempaka tidak ada sama sekali.

Transaksi yang menguntungkan menarik orang lokal maupun mancanegara untuk ikut aktif dalam kegiatan ekonomi di tambang rakyat. Mereka tertarik bukan hanya untuk menjadi pemilik modal, tetapi secara umum menjadi pembeli intan-intan tersebut. Kepala Dinas Pertambangan dan Lingkungan Hidup (PLH) Kota Banjarbaru, Burhanuddin mengungkapkan dalam Media Indonesia bahwa besarnya potensi Pendapatan Asli Daerah atau PAD yang bisa didapat dari transaksi intan di Cempaka. Namun Pemerintahan Kota mengalami kesulitan dalam menjaring pendapatan dari sektor tersebut dikarenakan pebisnis melakukan transaksi secara sembunyi-sembunyi. "Mereka biasanya menghindar jïka ada orang tak dikenal saat transaksi", katanya.

As'ad (2005:4) menyebutkan bahwa Pemerintah Kota Banjarbaru tetap diam dan seolah serba kikuk menata pertambangan rakyat di daerahnya. Kilauan intan Cempaka ternyata tak mempercantik Banjarbaru yang kini sibuk bersolek. Di kala sibuk bersolek, tidak seharusnya Banjarbaru melupakan nasib para pendulang. Walaupun Pemkot Banjarbaru telah melakukan usaha penertiban penambangan rakyat, yaitu dengan diterbitkannya Perda Nomor 05 Tahun 2002 tentang Pengelolaan Usaha Pertambangan Rakyat Bahan Galian Strategis dan Vital (Golongan A dan B). 


\section{METODE PENELITIAN}

Penulis menggunakan pendekatan kualitatif dalam penelitian ini. Penelitian ini menggunakan data sekunder sebagai sumber utama sehingga metodenya adalah secondary analysis. Data sekunder yang digunakan dalam penelitian ini pertama dari hasil riset terdahulu, termasuk hasil riset penulis sebelumnya dan data sekunder kedua dari Pemerintah Daerah serta UndangUndang terkait masalah. Sumber dari data sekunder tersebut penulis sertakan di daftar pustaka. Data sekunder yang penulis gunakan kemudian dianalisis dengan menggunakan konsep dalam Sosiologi Ekonomi, khusunya terkait dengan sektor informal dan free rider.

\section{KERANGKA TEORI / KONSEP}

Dalam melakukan analisis terhadap konteks kasus di atas, penulis memfokuskan pada dua hal, yang pertama yaitu peran-peran yang sedang dimainkan oleh aktor-aktor dalam tambang rakyat tersebut, baik itu pendulang, pengusaha atau pedagang, pemerintah kota, Kadin dan lembaga profesi. Kedua, penulis memfokuskan pada analisis terhadap kegiatan ekonomi yang berlangsung. Adapun konsep-konsep Sosiologi Ekonomi yang akan penulis pakai untuk menganalisis adalah :

\begin{tabular}{ll}
\hline Konsep & \multicolumn{1}{c}{ Penjelasan } \\
\hline Free Rider & Mancur Olson (Haryanto 2011:43) mengemukakan sebuah fenomena free \\
& rider atau pembonceng gratis. Fenomena yang menunjukkan adanya perilaku \\
& yang dimotivasi untuk memaksimalkan keuntungan dan meminimalkan biaya \\
& (cost). Konsep ini menginspirasi Granovetter yang menulis tentang teori \\
& tindakan kolektif. Teori tindakan kolektif Granovetter terletak pada motif \\
& seseorang dalam berpartisipasi. Partisipasi seseorang ditentukan oleh \\
& distribusi manfaat yang ia peroleh dalam kegiatan kolektif, bukannya oleh \\
& keinginan untuk berpartisipasi. \\
\hline Sektor Informal & Istilah ini merujuk pada fenomena sektor informal yang tidak mengikuti \\
& aturan-aturan yang dikeluarkan pemerintah. Aktivitas ekonomi jenis ini pada \\
& umumnya berada di luar regulasi hukum, sistem pencatatan perusahaan, \\
& perpajakan, dan juga perlindungan tenaga kerja. Shadow Economy merupakan \\
& berbagai kegiatan ekonomi yang berskala kecil sehingga bisa dipandang \\
& efisien dalam memberikan pelayanan karena mampu memotong rantai \\
& perdagangan dan memudahkan pelanggan dalam memperoleh barang dan \\
& jasa yang murah. Sifat sektor ini adalah mendekatkan diri kepada konsumen. \\
& Dari sisi produksinya, kegiatan ini bersifat subsisten yang bernilai ekonomis \\
& dalam pemenuhan kebutuhan sehari-hari, khususnya bagi masyarakat yang \\
& ada di lingkungan sektor infomal. Produksi dan jasa yang dihasilkan hanya \\
& mampu memenuhi kebutuhan pelaku sektor informal dalam batas yang \\
& minimal. \\
& Gilbert dan Gugker (Haryanto 2011:231), menandai sektor informal dengan \\
& ciri-ciri: (a) mudah dimasuki, (b) bersandar pada sumber daya lokal, (c) usaha \\
& milik sendiri, (d) operasinya dalam skala kecil, (e) padat karya dan \\
& teknologinya bersifat adoptif, (f) keterampilan dapat diperoleh di luar sistem \\
& sekolah formal, dan (g) tidak terkena langsung oleh regulasi dan pasarnya \\
& bersifat kompetitif. \\
& Menurut ILO (Haryanto 2011:231), sektor informal adalah sektor yang \\
mudah dimasuki oleh pengusaha atau pendatang baru, menggunakan
\end{tabular}


sumber-sumber ekonomi dalam negeri, usaha ekonomi yang dimiliki keluarga, berskala kecil, menggunakan teknologi padat karya, dan teknologi disesuaikan dengan keterampilan yang dibutuhkan tidak diatur oleh pemerintah dan bergerak dalam pasar penuh persaingan.

\section{PEMBAHASAN}

Kasus tambang rakyat Intan Cempaka Banjarbaru, Kalimantan Selatan seperti yang telah penulis paparkan di atas, ada beberapa hal yang mesti digarisbawahi untuk melihat aktivitas ekonomi seperti apa yang berlangsung. Yang terpenting adalah menggaris bawahi bagaimana peran pemerintah di dalamnya. Ungkapan dari perwakilan Pemerintah Kota Banjarbaru bahwa transaksi intan pada tambang rakyat Cempaka tidak ada kontribusinya terhadap Pendapatan Asli Daerah (PAD) membuktikan bahwa ada sesuatu yang tidak beres dalam tambang ini.

Tambang rakyat intan di Cempaka memang bukan tambang yang cukup besar, namun transaksi yang melingkupi tambang tersebut cukup besar. Kalau ingin melihat bagaimana hasil dari tambang tersebut maka pergilah ke pertokoan permata Cahaya Bumi Selamat di Martapura, di sanalah pintu keluar intan ke daerah-daerah di Indonesia bahkan ke luar negeri. Hidup pendulang yang berada jauh di bawah standar kesejahteraan jika dilihat dari kepemilikan baik tempat tinggal maupun pendidikan, merupakan hal yang ironis. Kalau pemerintah tidak mendapat hasil dari transaksi intan dan pendulang juga tidak mendapat hasil sepantasnya untuk kesejahteraan, lalu kemana hasil dari transaksi yang nilainya tidak kecil tersebut?

Tidak adanya kontribusi atas transaksi intan pada Pemerintah Kota membuktikan bahwa aktivitas ekonomi tersebut bersifat informal. Namun tidak seperti yang dicirikan oleh aktivitas ekonomi sektor informal yang penulis sebutkan, yaitu "...pada umumnya berada di luar regulasi hukum, sistem pencatatan perusahaan, perpajakan, dan juga perlindungan tenaga kerja". Tambang tersebut tidak berada di luar regulasi hukum, ada hukum atau peraturan pemerintah yang mengaturnya. Bahkan peraturan yang mengatur tambang rakyat intan pernah dikeluarkan Belanda saat menjajah Indonesia, yaitu : "Peraturan yang mengatur tambang rakyat di Indonesia secara khusus untuk tambang intan telah ada sejak tahun 1923. Pemerintah kolonial Belanda mengeluarkan Ordonantie tanggal 25 Nopember 1923 Staatblats 1923 No. 565 yang mencabut Ordonantie tanggal 7 Juni 1900 Staatblats 1900 No. 174. Pengaturan ini memuat ketentuan diantaranya: (1) Pertambangan intan tanpa konsesi di Martapura dan Pelaihari hanya boleh dilakukan oleh penduduk setempat. (2) Bagi penambang yang menambang tanpa menggunakan mesin harus seijin residen dan harus membayar f. 0,5 per 6 bulan. (3) Bagi penambang yang menambang dengan menggunakan mesin harus memperoleh ijin menyewa 
dari residen dan dikenai ongkos sewa sebanyak f. 0,4 per meter per tahun. Penambang juga diwajibkan membuat batas wilayahnya dengan biaya sendiri. (4) Bagi yang melakukan penambangan tanpa ijin dikenai hukuman kurungan 1 tahun dan denda paling tinggi f. 100”. Pemerintah Kota Banjarbaru juga telah mengeluarkan Peraturan Daerah (Perda) Nomor 05 Tahun 2002 tentang Pengelolaan Usaha Pertambangan Rakyat Bahan Galian Strategis dan Vital (Golongan A dan Golongan B). Ijin sebagai wilayah Pertambangan (WPR) memang sudah ada tetapi ijin atas aktifitas yang dilakukan dalam tambang tersbeut belum ada. Hingga sampai saai ini tidak ada IPR (Ijin Pertambangan Rakyat) pada tambang rakyat Intan di Cempaka, Banjarbaru tersebut.

Sebenarnya apa keuntungan jika aktivitas dalam tambang rakyat intan Cempaka tersebut berada di luar regulasi hukum? Pertama tentu saja dalam hal ekonomi, tidak ada retribusi atau biaya apa pun yang mesti dibayar aktor di tambang kepada pemerintah karena memang keberadaannya dianggap tidak ada. Kedua, tidak ada kewajiban bagi aktor dalam tambang dalam melaporkan apa saja yang terjadi di tambang rakyat intan Cempaka tersebut. Ketiga, tidak ada kewajiban dalam persoalan lingkungan bagi aktor dalam tambang rakyat. Yang saya maksud sebagai kewajiban persoalan lingkungan di sini adalah kewajiban untuk mematuhi AMDAL terutama yang berkaitan dengan limbah dan juga mengembalikan lubang ke posisi semula atau menutup lubang setelah selesai digali.

Belum lagi terkait definisi selanjutnya dalam sektor informal yaitu tidak adanya perlindungan terhadap tenaga kerja. Yang perlu ditekankan di sini adalah bahwa kegiatan ekonomi di tambang tersebut, bukanlah kegiatan yang dibawahi oleh sebuah perusahaan. Tidak ada perusahaan yang mengatur kegiatan ekonomi di sana. Sehingga mengatur pajaknya pun menjadi hal yang sulit. Pemerintah tidak bisa menjerat persoalan pajak pada transaksi intan tersebut. Apalagi berkenaan dengan perlindungan terhadap tenaga kerja, tiap-tiap manusia yang bekerja di tambang tersebut bertanggung jawab atas keselamatan dirinya sendiri. Tidak ada yang bertanggung jawab terhadap perlindungan ataupun keselamatan pekerja. Hal ini dikarenakan mereka bekerja tanpa diikat oleh kontrak dengan pihak mana pun, mereka bekerja atas nama pribadi dan dengan kehendak pribadi. Persoalan perlindungan terhadap pendulang memang menjadi problem yang sulit untuk diatasi.

Apakah kegiatan ekonomi di tambang rakyat tersebut bisa dikategorikan sebagai Shadow Economy? Ada beberapa poin seperti yang telah penulis kutip di atas, bahwa "Shadow Economy merupakan berbagai kegiatan ekonomi yang berskala kecil sehingga bisa dipandang efisien dalam memberikan pelayanan karena mampu memotong rantai perdagangan dan 
memudahkan pelanggan dalam memperoleh barang dan jasa yang murah". Kegiatan ekonomi di tambang rakyat intan memang berskala kecil dan memang bisa memotong mata rantai perdagangan, karena penjual datang langsung ke lokasi tambang.

Penulis mencoba menganalisis kegiatan ekonomi di tambang rakyat intan tersebut dengan ciriciri sektor informal yang dikemukakan oleh Gilbert dan Gugker yang telah penulis kutip. Tambang rakyat intan memang mudah untuk dimasuki, artinya cukup mengenal salah satu dari pendulang yang bekerja di tambang tersebut dan meminta ijin kepada perwakilan dari mereka, sekedar sebagai etika masuk, maka siapa pun bisa menjabat sebagai pendulang. Karena tambang maka sudah pasti kegiatan ekonomi di sana sangat bersandar pada sumber daya lokalnya yaitu intan yang ada di perut bumi dalam lokasi tersebut. Seperti yang penulis sebutkan, bahwa kegiatan ekonomi dalam tambang rakyat intan memang dalam skala kecil. Menjadi pendulang atau pun pedagang intan dalam kegiatan ekonomi tambang rakyat intan memang membutuhkan keterampilan yang diperoleh di luar sistem sekolah formal.

Peran pemerintah yang minim di dalam regulasi kegiatan ekonomi tambang rakyat memang terlihat dari tidak adanya kontribusi tambang yang tercatat dalam PAD. Namun seperti yang dijelaskan di atas, tambang tersebut tidak berada di luar regulasi hukum, ada peraturan pemerintah yang mengaturnya. Sehingga menurut hemat penulis, pemerintah sebagai institusi kurang menyentuh tambang rakyat tersebut, sehingga peraturan yang dibuat pun realisasinya minim. Harusnya pemerintah sebagai institusi yang punya kekuatan dan kekuasaan bukan hanya sekedar menciptakan peraturan, tapi juga membuat bagaimana caranya peraturan tersebut terealisasi di konteksnya. Pemerintah punya kewajiban dalam mengatur, sehingga distribusi keuntungan dari tambang rakyat khusunya bisa dinikmati oleh pendulang dan masyarakat sekitar tambang, pemerintah juga punya kewajiban dalam melindungi keselamatan pendulang. Sejauh yang penulis ketahui tidak ada peran Kadin dalam tambang rakyat tersebut. Begitu juga lembaga profesi lain. Sebagai sebuah sektor informal, tambang rakyat jelas perlu diperhatikan dengan teliti oleh Pemerintah.

Selanjutnya penulis akan mencoba menganalisis kasus dengan konsep free rider. Free rider atau pembonceng gratis, bisa diartikan sebagai orang yang mengambil keuntungan dalam transaksi kegiatan ekonomi tanpa memiliki modal. Dalam tambang tersebut, beberapa pendulang tidak terikat dengan pemilik modal, sehingga dia bisa menjual intannya kepada siapa saja. Namun beberapa dari mereka tidak punya jaringan pedagang intan. Padahal intan yang didapat hari itu akan mereka jual hari itu juga untuk kebutuhan sehari-hari keluarga. Disinilah free rider memiliki kesempatan untuk masuk dan terlibat serta mengambil keuntungan. Free rider dalam tambang 
rakyat tersebut bertindak sebagai orang ketiga yang menghubungkan pendulang dengan pembeli intan, atau menjadi orang ketiga antara pemilik intan (bukan pendulang, bisa jadi pemilik tanah atau pemilik mesin) dengan pembeli intan. Sebagai orang ketiga harga jual intan yang diberikan pendulang akan dinaikkan untuk keuntungan pribadi. Sedangkan dalam negosiasinya dengan pendulang/pemilik intan, free rider akan berusaha agar harga yang ditetapkan pendulang rendah. Hal ini agar bisa menjual intan tersebut dengan harga yang lebih tinggi, di mana selisih dengan harga yang ditentukan pendulang adalah keuntungannya.

Free rider terus berkembang dalam pertambangan rakyat dikarenakan minimnya resiko. Kalau berperan sebagai pendulang, atau pemilik tanah, atau pemilik mesin atau pedagang maka ada resiko kerja serta biaya kerja yang harus ditanggung. Tetapi kalau menjadi free rider atau di tambang rakyat intan sering disebut dengan istilah "pengempet" maka resiko serta biaya tidak ada, dan keuntungan dalam jumlah yang lebih akan didapatkan.

\section{SIMPULAN}

Tambang rakyat intan di Cempaka, Banjarbaru, Kalimantan Selatan merupakan jenis sektor ekonomi informal. Aktifitas ekonomi di dalamnya diketahui pemerintah, namun dibiarkan. Sebagai sektor ekonomi harusnya tambang rakyat menjadi penunjang kesejahteraan ekonomi masyarakat setempat yang berprofesi sebagai pendulang. Namun, yang terjadi justru pihakpihak luar yang bukan berprofesi sebagai pendulang atau pemilik tanah atau pemilik mesin yang mendapat keuntungan yang besar dari aktifitas ekonomi sektor informal dalam tambang rakyat. Mereka yang memperoleh keuntungan tersebut kebanyakan adalah para pembonceng gratis atau yang disebut Granovetter dengan istilah free rider. Free Rider adalah mereka yang sebenarnya tidak memiliki modal dalam aktifitas pertambangan tetapi mengambil keuntungan dari adanya pertambangan tersebut. Free Rider dalam tambang rakyat akan terus meningkat seiring dengan tidak adanya peran pemerintah dalam mengatur atau membina aktivitas ekonomi yang melingkupi tambang rakyat itu sendiri. Sektor informal menjadi lahan subur bagi peningkatan jumlah dan peran free rider.

\section{DAFTAR PUSTAKA}

As'ad. 2005. Pengelolaan Lingkungan Pada Penambangan Rakyat (Studi Kasus Penambangan Intan Rakyat di Kecamatan Cempaka Kota Banjarbaru Propinsi Kalimantan Selatan). Tesis. Tidak Diterbitkan.

Azkia, Laila. 2010. Pemanfaatan Momen Produktif Dalam Tambang Raktar : Sebuah Aplikasi Soft Sytems Methodology (SSM). Tesis. Tidak Diterbitkan.

Granovetter, Mark. 2005. “The Impact of Social Structure on Economic Outcomes.” Journal of Economic Perspectives 19(1).

Haryanto, Sindung. 2011. Sosiologi Ekonomi. Yogyakarta: Ar-Ruzz Media. 
Laila Azkia

Hilson, Gavin M. 2005. The Socio Economics Impacts of Artisanal and Small-Scale Mining in Developing Countries. Netherlands: A.A Balkema Publishers.

Smelser, Niel J and Richard Swedberg. 2005. The Handbook of Economic Sociology. Princeton: Princeton University Press.

69 | SUSIOGLLBAL : Jurnal Pemikiran dan Penelitian Sasiologi, Vol. 3., No. I, Desember 2018 